\title{
Appendix 3: List of respondents
}

\section{LIST OF INTERVIEWS FOR CHAPTER 5}

1. Online interview (Skype) with a member state representative to COEST, 30 October 2020 (COEST respondent 1).

2. Online interview (Skype) with a member state representative to COEST, 10 November 2020 (COEST respondent 2).

3. Online interview (Zoom) with a member state representative to COEST, 27 October 2020 (COEST respondent 3).

4. Online interview (Webex) with a member state representative to COEST, 10 November 2020 (COEST respondent 4).

5. Online interview (Skype) with a member state representative to COEST, 9 November 2020 (COEST respondent 5).

6. Online interview (Microsoft Teams) with a member state representative to COEST, 13 November 2020 (COEST respondent 6).

7. Online interview (Skype) with a member state representative to COEST, 29 October 2020 (COEST respondent 7).

8. Online interview (Webex) with a member state representative to COEST, 29 October 2020 (COEST respondent 8).

9. Online interview (Webex) with a member state representative to PMG, 17 November 2020 (PMG respondent 1).

10. Online interview (Teams) with a member state representative to PMG, 2 November 2020 (PMG respondent 2).

11. Online interview (Teams) with a member state representative to PMG, 13 November 2020 (PMG respondent 3).

12. Online interview (Webex) with a member state representative to $\mathrm{PMG}, 10$ November 2020 (PMG respondent 4).

13. Online interview (Webex) with a member state representative to PMG, 17 November 2020 (PMG respondent 5).

\section{LIST OF INTERVIEWS FOR CHAPTER 6}

1. Personal interview with a Deputy Permanent Representative to the PSC, Brussels, 5 October 2016 (PSC respondent 1). 
2. Personal interview with a Permanent Representative to the PSC, Brussels, 4 October 2016 (PSC respondent 2).

3. Telephone interview with a Permanent Representative to the PSC, 13 October 2016 (PSC respondent 3).

4. Personal interview with a Permanent Representative to the PSC, Brussels, 3 October 2016 (PSC respondent 4).

5. Personal interview with a Deputy Permanent Representative to the PSC, Brussels, 5 October 2016 (PSC respondent 5).

6. Telephone interview with a Deputy Permanent Representative to the PSC, 21 October 2016 (PSC respondent 6).

7. Personal interview with a Permanent Representative to the PSC, Brussels, 3 October 2016 (PSC respondent 7).

8. Personal interview with a Permanent Representative to the PSC, Brussels, 7 October 2016 (PSC respondent 8).

9. Personal interview with a Permanent Representative to the PSC, Brussels, 5 October 2016 (PSC respondent 9).

10. Personal interview with a Permanent Representative to the PSC, Brussels, 5 October 2016 (PSC respondent 10).

11. Personal interview with a Deputy Permanent Representative to the PSC, Brussels, 3 October 2016 (PSC respondent 11).

12. Personal interview with a Permanent Representative to the PSC, Brussels, 29 November 2017 (PSC respondent 12).

13. Personal interview with a Permanent Representative to the PSC, Brussels, 29 November 2017 (PSC respondent 13).

14. Personal interview with a Permanent Representative to the PSC, Brussels, 16 November 2017 (PSC respondent 14).

15. Personal interview with a Deputy Permanent Representative to the PSC, Brussels, 16 November 2017 (PSC respondent 15).

16. Personal interview with a Permanent Representative to the PSC, Brussels, 15 November 2017 (PSC respondent 16).

17. Personal interview with a Permanent Representative to the PSC, Brussels, 29 November 2017 (PSC respondent 17).

18. Personal interview with a Permanent Representative to the PSC, Brussels, 16 November 2017 (PSC respondent 18).

19. Personal interview with a Permanent Representative to the PSC, Brussels, 28 November 2017 (PSC respondent 19).

20. Personal interview with a Permanent Representative to the PSC, Brussels, 15 December 2017 (PSC respondent 20).

21. Personal interview with Permanent Representative to the PSC, Brussels, 17 May 2019 (PSC respondent 21).

22. Telephone interview with a Permanent Representative to the PSC, 27 May 2019 (PSC respondent 22). 
23. Personal interview with a Permanent Representative to the PSC, Brussels, 17 May 2019 (PSC respondent 23).

24. Personal interview with a Deputy Permanent Representative to the PSC, Brussels, 17 May 2019 (PSC respondent 24).

25. Personal interview with a Permanent Representative to the PSC, Brussels, 15 May 2019 (PSC respondent 25).

\section{LIST OF INTERVIEWS FOR CHAPTER 7}

1. Personal interview with EEAS official, Stockholm, 26 November 2015 (EEAS respondent 1).

2. Video interview with EEAS official, 31 August 2016 (EEAS respondent 2).

3. Telephone interview with EEAS official, 03 September 2016 (EEAS respondent 3).

4. Personal interview with EEAS official, Brussels, 30 November 2016 (EEAS respondent 4).

5. Personal interview with EEAS official, Brussels, 30 November 2016 (EEAS respondent 5).

6. Personal interview with EEAS official, Brussels, 30 November 2016 (EEAS respondent 6).

7. Personal interview with EEAS official, Brussels, 30 November 2016 (EEAS respondent 7).

8. Personal interview with EEAS official, Brussels, 30 November 2016 (EEAS respondent 8).

9. Personal interview with EEAS official, Brussels, 1 December 2016 (EEAS respondent 9).

10. Personal interview with EEAS official, Brussels, 1 December 2016 (EEAS respondent 10).

11. Personal interview with EEAS official, Brussels, 2 December 2016 (EEAS respondent 11).

12. Personal interview with EEAS official, Brussels, 2 December 2016 (EEAS respondent 12).

13. Personal interview with EEAS official, Brussels, 2 December 2016 (EEAS respondent 13).

14. Telephone interview with EEAS official, 28 November 2017 (EEAS respondent 14).

15. Telephone interview with EEAS official, 4 April 2018 (EEAS respondent 15).

16. Personal interview with EEAS official, Brussels, 24 April 2018 (EEAS respondent 16). 
17. Personal interview with EEAS official, Brussels, 24 April 2018 (EEAS respondent 17).

18. Personal interview with EEAS official, Brussels, 24 April 2018 (EEAS respondent 18).

19. Personal interview with EEAS official, Brussels, 24 April 2018 (EEAS respondent 19).

20. Personal interview with EEAS official, Brussels, 26 April 2018 (EEAS respondent 20).

21. Personal interview with EEAS official, Brussels, 26 April 2018 (EEAS respondent 21).

22. Personal interview with EEAS official, Brussels, 26 April 2018 (EEAS respondent 22).

23. Personal interview with EEAS official, Brussels, 26 April 2018 (EEAS respondent 23).

24. Personal interview with EEAS official, Brussels, 16 May 2019 (EEAS respondent 24).

25. Video interview with EEAS official, 17 September 2020 (EEAS respondent 25).

26. Video interview with EEAS official, 14 April 2021 (EEAS respondent 26).

27. Video interview with EEAS official, 14 April 2021 (EEAS respondent 27).

\section{LIST OF INTERVIEWS FOR CHAPTER 8}

1. Personal interview at an EU member state embassy, Washington, November 2019 (EU MS 1).

2. Personal interview at an EU member state embassy, Washington, November 2019 (EU MS 2).

3. Personal interview at an EU member state embassy, Washington, November 2019 (EU MS 3).

4. Personal interview at an EU member state embassy, Washington, November 2019 (EU MS 4).

5. Personal interview at an EU member state embassy, Washington, November 2019 (EU MS 5).

6. Personal interview at an EU member state embassy, Beijing, December 2019 (EU MS 6).

7. Telephone interview with a senior official at an EU member state embassy, Washington, December 2019 (EU MS 7).

8. Personal interview at the EU delegation, Washington, November 2019 (EU delegation 1). 
9. Personal interview at the EU delegation, Beijing, December 2019 (EU delegation 2).

10. Personal interview at the EU delegation, Seoul, December 2019 (EU delegation 3).

\section{LIST OF RESPONDENTS AND INTERVIEWS FOR CHAPTER 9}

1. Survey response from EEAS official, March 2021 (EEAS respondent 1).

2. Survey response from EEAS official, March 2021 (EEAS respondent 2).

3. Survey response from Council representative, April 2021 (Council respondent 1).

4. Survey response from EEAS official, April 2021 (EEAS respondent 3).

5. Survey response from Council representative, April 2021 (Council respondent 2).

6. Survey response from EUISS representative, April 2021 (EUISS respondent 1).

7. Survey response from Council representative, April 2021 (Council respondent 3).

8. Survey response from ESDC representative, April 2021 (ESDC respondent 1).

9. Survey response from ESDC, April 2021 (ESDC respondent 2).

10. Video interview with EEAS official, 27 March 2020 (EEAS respondent 4).

11. Video interview with EEAS official, 27 March 2020 (EEAS respondent 5).

12. Video interview with EEAS official, 14 April 2021 (EEAS respondent 6).

13. Video interview with EEAS official, 14 April 2021 (EEAS respondent 7). 